\title{
Rinnakkaistallentamisen edistäminen organisaatiotasolla - kokemuksia ja päätelmiä Hankenin NopSA-hankkeesta
}

\author{
Mikael Laakso \\ Hanken \\ mikael.laakso@hanken.fi \\ http://orcid.org/0000-0003-3951-7990 \\ Linus Nyman \\ Hanken \\ linus.nyman@hanken.fi \\ http://orcid.org/0000-0001-5051-1683 \\ Bo-Christer Björk \\ Hanken \\ bo-christer.bjork@hanken.fi \\ http://orcid.org/0000-0003-1545-9642
}

This case study reports about a project (NopSA) aimed at increasing the open access (OA) of research publications from the faculty at a Finnish business school, Hanken School of Economics. The project included outreach and advocacy to faculty, as well as changing practices and the university's OA policies. The primary focus of the project was on increasing self-archiving of articles in the school's institutional repository (both retroactively and on a continuous basis in the future). A secondary focus was on understanding researcher views concerning various OA options, and ultimately informing and establishing sustainable OA policies at the organisational level.

Asiasanat: rinnakkaistallentaminen; openaccess; yliopistot

VERTAISARVIOITU

WERTAISARVIOITU
KOLLEGIALT GRANSKAD
EER-REVIEWED

PEER-REVIEWED
www.tsv.fi/tunnus 
Avoin julkaiseminen (Open Access, OA) on ollut jatkuvassa kasvussa jo parin vuosikymmenen ajan, mutta läpimurto on monella tavalla ollut odotettua hitaampaa, kuin mitä moni osasi alkuaikoina odottaa (Holopainen \& Koskinen, 2016). OA voi toteutua joko suoraan tiedelehden kautta niin, että artikkeli julkaistaan avoimesti suoraan tiedelehden sivuilla, tai niin että tutkija rinnakkaistallentaa artikkelin (tai sen käsikirjoitusversion) julkaisuarkistoon (Björk, Laakso, Welling, \& Paetau, 2014).

Viime vuodet avoin tiede, ja varsinkin avoin julkaiseminen sen yhtenä keskeisenä osana on ollut vahvasti esillä tiedepolitiikassa niin Suomessa kuin ulkomailla (Euroopan Komissio, 2016; OKM, 2014). Yksi keskeinen haaste avoimeen julkaisemiseen siirtymisessä on se, että kaikilla tieteenaloilla ei vielä ole tarpeeksi kattavasti arvostettuja avoimesti julkaisevia tiedelehtiä, vaan tilauspohjaiset lehdet muodostavat vielä suurimman osan kaikista keskeisistä lehdistä. OA-lehdet ovat jalkautuneet hyvin epätasaisesti riippuen tieteenalasta. Poikkeuksellisen vahvoilla on lääketieteen tiedeala jossa OA-lehdet ovat niin lehtien määrän kuin myös tieteellisen laadun mittareilla hyvin edustettuna (Ennas \& Di Guardo, 2015; Poltronieri, Bravo, Curti, Ferri, \& Mancini, 2016). Mitä tulee Suomen tutkimuskentän haasteisiin, Holopainen (2014) totesi katsauksessaan 2014, että OA-lehtiä oli kaiken kaikkiaan hyvin niukasti lehtien ja sarjojen JUFO-luokitteluasteikon korkeimmilla sijoilla. Vuoden 2016 tilastojen mukaan OA-lehtiä oli JUFOssa tasolla nolla $153 \mathrm{kpl}$, tasolla yksi $574 \mathrm{kpl}$, tasolla kaksi $19 \mathrm{kpl}$ ja tasolla kolme (korkein) vain $8 \mathrm{kpl}$ (Ruth, 2016). Toinen keskeinen haaste OA-julkaisemisen yleistymiselle on OA-lehtien tavallisesti perimät kirjoittajamaksut ja näiden rahoitusmekanismien puuttuminen tutkijoiden ja yliopistojen puolelta. Tuoreen kartoituksen mukaan vuonna 2015 55 \% DOAJ-indeksiin sisältyvissä OA-lehdissä julkaistuista artikkeleista perittiin maksu, ja näiden maksujen keskihinta oli 1219 dollaria. Loput $45 \% 2015$ vuoden artikkeleista julkaistiin kirjoittajille ilmaisissa lehdissä (Crawford, 2016). Yleisesti kirjoittajamaksuihin tarvittavat rahat saadaan katettua rahoitetun projektin kautta, sillä useimmat rahoittajat, mukaan lukien Suomen Akatemia ja Europan unioni, hyväksyvät tällaisia kustannuksia hankerahoituksissaan (Euroopan Komissio, 2016; Suomen Akatemia, 2015). Kirjastoilla on jo lehtien tilauspohjaisten aineistojen kustannusten kattamisessa haastetta, ja ainakaan vielä ei yleisesti ole erillistä rahoitusta varattu tällaisiin tarkoituksiin. On laskettu, että kaikki suomalaisten tutkijoiden tuottamien artikkeleiden kirjoittajamaksut olisi mahdollista kattaa tiedelehtien nykyisillä tilaushinnoilla (Ilva, Laitinen, \& Saarti, 2016), mutta niin kauan kuin suurin osa tiedelehdistä pysyy tilauspohjaisina ja niiden tilaushinnat jatkuvassa nousussa, nykyisen julkaisutoiminnan tukemiseen tarkoitetusta rahoituksesta ei vapaudu resursseja avoimen julkaisemiseen laajalla mittakaavalla. 
Rinnakkaistallentamisella, eli käytännöllä jossa tilauspohjaisessa lehdessä julkaistun artikkelin käsikirjoitusversio tai parhaimmassa tapauksessa lopullinen versio saatetaan avoimesti saatavaksi, on valtava käyttämätön potentiaali saattaa tiedelehtien artikkeleita kaikkien käyttöön. Suurin osa tiedelehtien artikkeleista (yli 80 \%) suo kirjoittajilleen luvan rinnakkaistallentaa artikkelin viimeisimmän käsikirjoitusversion vertaisarvion jälkeisillä muutoksilla oman yliopiston tai tiedealakohtaiseen julkaisuarkistoon vuoden viiveellä julkaisemisesta pyytämättä erillistä lupaa julkaisijalta (Laakso, 2014; University of Nottingham, 2016). Toisin kuin julkaiseminen avoimissa tiedelehdissä, rinnakkaistallentaminen ei vaadi tutkijoilta muutoksia julkaistavan tiedelehden valinnassa. Mitään maksuja ei myöskään peritä, jolloin erillistä rahoitusta ei tarvita, mikä on suuri etu verrattuna useimpien tilauspohjaisten lehtien tarjoamaan hybridi OA-vaihtoehtoon, jolloin yhden artikkelin avoin julkaiseminen lehdessä maksaa tuhansia euroja (Laakso \& Björk, 2016). Avoimen julkaisemisen kasvu on rinnakkaistallentamisen suhteen kuitenkin ollut enimmäkseen hidasta suurimmassa osassa maailmaa (Archambault ym., 2014).

Tämän asetelman parantaminen avoimen julkaisemisen osalta voidaan kiteyttää yhteen keskeiseen kysymykseen, joka toimii sekä tutkimuskysymyksenä että koko hankkeen keskeisenä konkreettisena pyrkimyksenä:

Miten tutkimusjulkaisuja tuottavat organisaatiot pystyvät nykytiedon valossa parhaiten tukemaan ja edistämään rinnakkaistallentamista oman organisaationsa tutkimuksen osalta?

Tämän kysymyksen ympäriltä alkoi Hanken Svenska Handelshögskolanin NopSAhankkeen (Nopea Siirtyminen Avoimuuteen) suunnittelu. NopSA-hankeen tekijät olivat alusta alkaen tietojärjestelmätieteiden ja kirjaston henkilökuntaa, yhdistäen näin niin tutkijalähtöisyyden sekä konkreettisen kytköksen kirjaston nykyiseen ja tulevaan toimintaan. NopSA oli yksi viidestä hankkeesta, jotka rahoitettiin opetusja kulttuuriministeriön ensimmäisen Tieto käyttöön -rahoituskierroksen kautta keväällä 2015, ja se toimi näin osana valtakunnallista Avoin tiede ja tutkimus (ATT) tiedepoliittista kehittämiskokonaisuutta. Muista samanaikaisesti rahoitetuista hankkeista yksi läheinen esimerkki on Jyväskylän yliopiston ja Itä-Suomen yliopiston SURIMA-hanke (Suomi rinnakkaistallentamisen mallimaaksi), joka keskittyi myös edistämään avointa julkaisemista rinnakkaistallentamisen kautta omissa organisaatioissaan (Olsbo, 2017).

Tämä artikkeli käsittelee NopSA-hankkeen eri vaiheita ja niiden kautta kerättyjä kokemuksia. Ensin käsitellään organisaatiokohtaiseen rinnakkaistallentamiseen liittyvät keskeisimmät aikaisemmat tutkimustulokset. Tämän jälkeen esitetään hankkeen konkreettiset tavoitteet, jonka jälkeen tarkastellaan hankkeen eri vaiheiden 
lähtökohtia, vaiheiden toteutusta sekä arvioidaan niiden vaikutuksia ja hyödyllisyyttä avoimen julkaisemisen edistämiseksi. Artikkelin lopuksi hankkeen kokemuksista keskustellaan kokonaisvaltaisesti peilaten aikaisempiin tutkimustuloksiin ja esittäen toimivaksi todetut menetelmät rinnakkaistallentamisen edistämiseksi.

\section{Aiemmat tutkimukset}

Tiedeyhteisössä on käyty kiivasta keskustelua rinnakkaistallentamisen roolista avoimen julkaisemisen mahdollistajana jo yli kahden vuosikymmenen ajan (Okerson \& O'Donnell, 1995). Jo varhaisissa keskusteluissa oli havaittavissa jakautumista kahteen leiriin: ne jotka peräänkuuluttavat kaiken kattavaa rinnakkaistallentamista, ja ne jotka toivovat avoimuuden tapahtuvan suoraan tiedelehtien kautta. Ja edelleen, 22 vuotta myöhemmin, eri maiden ja tutkimusrahoittajien avoimuutta edistävät linjaukset sisältävät näiden eri mekanismien eri priorisointeja ja yhdistelmiä (Johnson \& Fosci, 2016). Moni yliopisto investoi julkaisuarkistoon ja sen jatkuvaan tekniseen ylläpitoon 200o-luvun alussa (Creaser ym., 2010), jolloin vallitsevana ajatuksena oli, että julkaisuarkistot ikään kuin täyttyisivät itsestään ja oman organisaation tutkijat hoitaisivat julkaisujen rinnakkaistallentamisen pääosin omatoimisesti (Salo, 2008). Näin ei kuitenkaan useimmiten ole käynyt, ja syitä julkaisuarkistojen tähänastista yleisesti alhaista käyttöastetta rinnakkaistallentamiseen on tarkasteltu eri näkökulmista, joita esitetään tässä lyhyesti.

NopSAn lähestymistapa pyrkiä edistämään rinnakkaistallennettujen julkaisujen määrää yhden organisaation kohdalla erilaisin keinoin, ja samalla kirjata kokemukset onnistumisiin ja kohdattuihin haasteisiin, ei ole uusi. Mercer, Rosenblum ja Emmett (2007) dokumentoivat Kansasin yliopiston kokemuksia siitä miten markkinoida ja nostaa julkaisuarkiston käyttöä omien tutkijoiden keskuudessa. Raportti korostaa linkittäjien (change agents) tärkeää roolia. Linkittäjät ovat henkilöitä, jotka toimivat siltana kirjaston ja tutkijoiden välillä. Nämä voisivat olla esimerkiksi tutkijoita, jotka ovat hyvin perillä tutkimustyön arjesta, rinnakkaistallentamisen eduista sekä osaavat neuvoa muita tutkijoita alkuun pääsemisessä. NopSA-projektissa tämä oli huomioitu kirjaston ja tietojenkäsittelytieteiden tutkijoiden yhteistyöllä, jossa varsinkin tutkijat olivat ne, jotka olivat ensisijaisesti yhteydessä muihin tutkijoihin. Tutkimuksellisempi kartoitus rinnakkaistallentamisen edistäjistä ja esteistä on teetetty Drexelin yliopiston julkaisuarkiston suhteen. Tutkimusmenetelminä olivat tutkijoiden haastattelut ja kysely (Goldman, Bhatt, \& Sieczkiewicz, 2010). Tämän tutkimuksen kautta kävi selväksi, että suuri osa tutkijoista oli tietämättömiä julkaisuarkiston toiminnasta ja rinnakkaistallentamisen mahdollisista eduista. Moni suhtaitui positiivisesti avoimeen julkaisemiseen, mutta tämä harvemmin kuitenkaan tarkoitti sitä, että tutkija olisi valmis muuttamaan julkaisukäytäntöjään tai ryh- 
tyisi rinnakkaistallentamaan. Myös Marquetten yliopisto on dokumentoinut omaa lähestymistapaansa julkaisuarkiston markkinointiin, johon sisältyi myös kyselyn teettäminen yliopiston tutkijoille ja jossa jo edellisen tutkimuksen kautta mainitut haasteet pitkälti toistuivat (Fortier \& Laws, 2014). Se, mikä näistä aikaisemmista tutkimuksista puuttuu, on bibliometrinen näkökulma siihen, paljonko organisaatio pystyy kasvattamaan rinnakkaistallentamista eri keinoin.

Tutkijoiden asenteita, kannustimia ja esteitä rinnakkaistallentamisen suhteen on tutkittu paljon eri näkökulmista. Tässä esitetään muutama keskeinen tutkimus sillä perusteella, että löydökset ovat pitkälti olleet samansuuntaisia myös muissa tutkimuksissa. Yksi keskeinen aikaisempi tutkijoihin keskittyvä tutkimus on Kim (2010), joka teetti kyselyn (684 professoria vastaajina) ja haastatteluita (41 professoria vastaajina) 17 yliopistossa Yhdysvalloissa. Muun muassa tutkijoiden ajan ja priorisoinnin puute, tekijänoikeuskysymysten epäselvyys ja tekniset haasteet tulivat esiin rinnakkaistallentamista rajoittavina tekijöinä. Suurin osa tutkijoista suoritti rinnakkaistallennusta suoraan omille verkkosivuilleen, tutkimusprojektin verkkosivuille tai laitoksen verkkosivulle. Alhaisin käyttöaste rinnakkaistallentamisessa oli yliopiston omalla julkaisuarkistolla (Kim, 2010). Tämän tutkimuksen kautta korostui julkaisuarkiston kilpailutilanne muiden verkossa sijaitsevien paikkojen kanssa, jotka tarjoavat mahdollisuuden omien julkaisujen saatavuuden kasvattamiseen ja jotka kuitenkin riittävät monelle tutkijalle. Viime vuosina yliopiston kanssa tutkijoiden huomiosta ja ajasta kilpailevat jakelukanavat kuten Academia.edu ja ResearchGate (Van Noorden, 2014), jotka pystyvät osin tarjoamaan joitakin avoimen saatavuuden hyötyjä sekä parantamaan julkaisujen näkyvyyttä ja löydettävyyttä sosiaalisten ominaisuuksien kautta (Niyazov ym., 2016). Näissä kaupallisissa palveluissa on kuitenkin monta epävarmuustekijää niin jatkuvan saatavuuden kuin tekijänoikeuksienkin osalta (Laakso \& Lindman, 2016; Rousi, 2016), joten niiden varaan kestävää avointa saatavuutta ei kannata rakentaa. Huomionarvoinen aikaisempi tutkijoihin keskittyvä tutkimus on myös Creaser ym. (2010) kyselytutkimus, johon vastasi 3139 EU:ssa toimivaa tutkijaa, ja jonka löydöksiä selkeytettiin ryhmähaastatteluiden kautta. Tämän tutkimuksen keskeisintä antia oli muun muassa tieto tutkijoiden keskuudessa vallitsevasta tietämättömyydestä organisaatiokohtaisen julkaisuarkiston tarkoituksesta ja epävarmuus omista oikeuksista sekä tiedelehtien vaatimasta viiveestä rinnakkaistallennuksen sallimisen suhteen.

Tärkeässä osassa rinnakkaistallentamisen tukemisessa organisaatiotasolla on myös yliopiston kirjasto, joiden kokemuksia ja mielipiteitä on myös kartoitettu tutkimusten kautta. Lagzian, Abrizah \& Wee (2015) teetti rinnakkaistallentamisen kriittisistä menestystekijöistä kyselytutkimuksen, jonka 322 vastaajaa olivat julkaisuarkistojen ylläpitäjiä, jotka ovat useimmiten yliopistojen kirjastojen henkilökuntaa. Yksityiskohtainen ja kvantitatiivisesti analysoitu kysely tuotti 46 yksittäistä vaikuttavaa tekijää ryhmitettynä kuuteen eri kategoriaan (hallinto, palvelut, teknolo- 
gia, rinnakkaistallentamisen käytännöt, ihmiset, resurssit). Tutkimus korosti tärkeänä ylemmän johdon vahvaa sitoutumista rinnakkaistallentamisen edistämiseen, asia joka oikein jalkautettuna motivoi myös tutkijat sekä mahdollistaa helppokäyttöisten teknisten ratkaisujen hankkimisen ja asianmukaisen resursoinnin kirjastossa.

Rinnakkaistallentamisen edistämiseksi organisaatiotasolla on yleistä, että organisaatio laatii ja julkaisee muodollisen linjausdokumentin, jossa ilmaistaan, millaisia konkreettisia pyrkimyksiä organisaatiolla on avoimen julkaisemisen suhteen, ja millä tavalla tutkijoiden odotetaan hoitavan omaa osuutta tämän pyrkimyksen tueksi. Näitä niin sanottuja OA-mandaatteja on monenlaisia, ne voivat sisältää tutkijoille suosituksen rinnakkaistallentamisesta tai sitten olla enemmän tai vähemmän pakottavia. Tutkimuksissa, joissa on kartoitettu eri OA-mandaattien sisältöjä ja niiden vaikutuksia organisaation rinnakkaistallennusasteeseen, on havaittu, että organisaatiot, joissa on tiukemmat vaatimukset rinnakkaistallennukselle, ja varsinkin jos rinnakkaistallennus on ehtona tutkimusjulkaisujen evaluointiin, rinnakkaistallennusta myös toteutuu enemmän (Swan, Gargouri, Hunt, \& Harnad, 2015; Vincent-Lamarre, Boivin, Gargouri, Larivière, \& Harnad, 2016). Tästä huolimatta pelkästään linjauksen julkaiseminen ei todennäköisesti riitä rinnakkaistallentamisen edistämiseksi. Organisaatiot, jotka ovat asettaneet lähes ehdottomia vaatimuksia rinnakkaistallentamiselle, ovat oletettavasti myös varmistaneet, että edellytykset hoitaa käytännön toimet ovat kunnossa. Ilman selkeää käytännön ohjeistusta, vahvaa organisaatiotasoista sitoutumista ja tehokkaita prosesseja toiminnan tueksi avoimen julkaisemisen todellinen potentiaali voi strategisista linjauksista huolimatta jäädä toteutumatta.

\section{Tutkimusmenetelmät ja -konteksti}

NopSAn tavoite oli kokonaisvaltaisesti parantaa Hankenin avoimen julkaisemisen käytäntöjä erityisesti rinnakkaistallentamisen kautta. Tavoite koski niin aikaisemmin julkaistuja teoksia kuin myös luomalla paremmat edellytykset avoimeen julkaisemiseen rinnakkaistallentamisen kautta tulevaisuudessa. Hanken, joka on Suomen pienin korkeakoulu, on mielenkiintoinen ympäristö merkittävän muutoksen kokeilemiseen - edellytykset sujuvalle ja yhtenäiselle kommunikaatiolle ja kokonaisvaltaiselle sekä yksilöidylle tuelle ovat olemassa. Hankenilla on Pure-pohjainen tutkimustietojärjestelmä, johon tutkijat itse rekisteröivät julkaisunsa. Se tarjoaa mahdollisuuden liittää julkaisutietoihin rinnakkaistallennettava versio julkaisusta, joka siirtyy kirjastohenkilökunnan hyväksynnän kautta pysyvästi DSpace-pohjaiseen julkaisuarkistoon. 


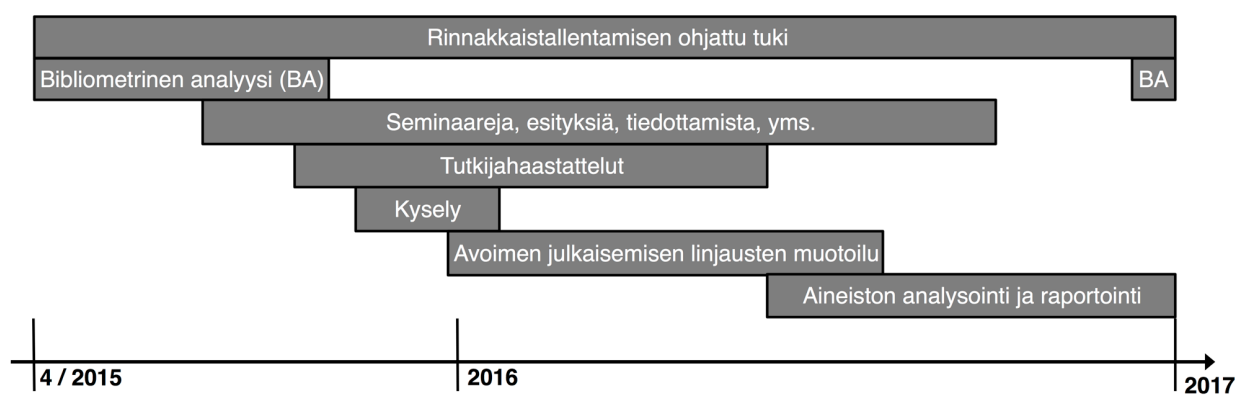

Kuva 1: NopSA-hankkeen aikajana

Asetimme NopSA-hankkeen tavoitteeksi lähteä kasvattamaan avoimen julkaisemisen astetta niin lähelle 80 \% vuosittaisista Hankenin tutkijoiden tuottamista vertaisarvioiduista tiedelehtien artikkeleista kuin suinkin vain mahdollista. Kaikki esteet tämän tason saavuttamiseksi yritettäisiin myös dokumentoida ja uusien linjausten kautta minimoida tulevaisuudessa. Hanke koostui karkeasti ottaen kolmesta eri vaiheesta: lähtötason kartoitus, tutkijoiden OA-näkemysten ja käytäntöjen tunnistaminen sekä muutoksen aikaansaaminen. Kuva 1 esittää hankkeen eri aktiviteetit aikajanalla alkaen huhtikuusta 2015 ja loppuen 31.12.2016.

Ennen kuin lähdimme vaikuttamaan avoimen julkaisemisen käytäntöihin, halusimme luoda kattavan yleiskatsauksen lähtötilanteesta, jonka kautta saisimme ymmärryksen tutkijoiden olemassa olevista rinnakkaistallentamisen käytännöistä, niin yksilö- kuin myös organisaatiotasolla. Lähtötason kartoitus oli myös tärkeässä roolissa, jotta NopSAn vaikutus olisi hankkeen loputtua mitattavissa. Tämän bibliometrisen analyysin kohteena oli vuosien 2012-2014 Hanken-affilioitujen tutkijoiden julkaisujen avoin saatavuus. Tästä alkukartoituksesta olemme jo tehneet yksityiskohtaisemmin selvityksen (Laakso, Lindman, Shen, Nyman, \& Björk, 2017), joten tässä yhteydessä esitämme vain lyhyen yhteenvedon tuloksista, jotta kartoituksen vaikutus myöhempiin vaiheisiin ja koko hankkeelle olisi ymmärrettävissä.

Suoritimme bibliometrisen kartoituksen jälkeen kyselyn, jonka kohteena olivat kaikki Hankenilla tutkimustyötä tekevät henkilöt, mukaan lukien vakituiset ja määräaikaiset työntekijät sekä jatko-opiskelijat. Kyselyä jaettiin paperimuodossa Hankenin vuosittaisessa tutkimuspäivä-tapahtumassa 12.11.2015 sekä myös sähköpostitse jälkikäteen joulukuussa 2015, jotta kaikilla olisi ollut mahdollisuus osallistua. Vastaajilta keräsimme tietoa heidän näkemyksistään avoimen julkaisemisen koetuista esteistä, mahdollistajista ja motivoivista tekijöistä. Kysymykset koskivat sekä rinnakkaistallentamista yleisesti että erityisesti Hankenin julkaisuarkiston käyttöä. Vastaajia pyydettiin ottamaan kantaa jokaiseen kysymykseen tai väitteeseen asteikolla $1-5$, jossa $1=$ olen täysin eri mieltä (I strongly disagree) ja $5=$ olen täysin sa- 
maa mieltä (I strongly agree). Kyselyyn saimme yhteensä 43 vastausta. Kysely tehtiin englanniksi, mutta tässä artikkelissa kysymykset ovat käännettynä suomeksi. Kyselyn tulokset analysoitiin deskriptiivisesti Excel-ohjelmistoa käyttäen ja suoria jakaumia tarkastelemalla.

Kyselyn jälkeen suoritimme vielä 10 tutkijahaastattelua, valikoiden vastaajat heidän korkean julkaisuaktiivisuutensa perusteella. Haastattelut toteutettiin vuoden 2015 syksystä vuoden 2016 kesään. Haastatteluissa oli mukana Hankenin molempien toimipaikkojen (Helsinki sekä Vaasa) edustajia. Haastattelun kieli valittiin haastateltavan toiveiden perusteella, käytännössä ne tehtiin joko englanniksi tai ruotsiksi. Semistrukturoidut haastattelut toteutettiin haastatteluoppaan avulla (Liite 1). Haastattelut toteutettiin kasvotusten, ja ne kestivät noin 15-40 minuuttia. Kaikki haastattelut nauhoitettiin ja litteroitiin analyysin helpottamiseksi. Analyysimenetelmänä käytimme sisältöanalyysia, jossa koodasimme tutkimuksille keskeisiä aiheita omiin ryhmiin. Aineiston selkeyden vuoksi analyysi suoritettiin tekstinkäsittelyohjelmaa käyttäen.

Kerättyämme bibliometrisen alkukartoituksen aineiston, kyselyaineiston sekä aloitettuamme tutkijahaastattelut aloitimme käytännön toimien suunnittelun niiden tulosten pohjalta. Kuten tuloksista selviää, tutkijat olivat jo pääsääntöisesti hyvin perillä avoimuuden tuomista hyödyistä, mutta julkaisuja ei yleensä oltu tallennettu julkaisuarkistoon julkaisijan edellyttämässä muodossa. Näin ollen avoimen julkaisemisen hyötyjen sijasta päätimme korostaa erityisesti julkaisuarkiston uniikkeja etuja. Näistä päällimmäiset ovat pysyvyys, kirjaston tarjoama apu ja vastuu tekijänoikeusasioiden selvittämisessä sekä näkyvyys hakupalveluiden indeksoinneissa. Tähän liittyen toteutimme useita eri aloitteita parantaaksemme takautuvasti tavoitevuosien rinnakkaistallentamisastetta sekä edistääksemme tulevaa rinnakkaistallentamista. Useimmat näistä aloitteista toteutettiin yhteistyössä kirjaston henkilökunnan kanssa.

1. Esitelmät Hankenin eri laitoksilla. Olimme Hankenin kaikkiin laitoksiin yhteydessä pyytäen aikaa tulla esittelemään rinnakkaistallentamisen mahdollisuuksia, näyttää miten se käytännössä tehdään kirjaston järjestelmien kautta sekä vastaamassa tutkijoiden kysymyksiin avoimesta julkaisemisesta. Esitykset pidettiin laitoskokousten yhteydessä, jotta kuuntelijamäärät olisivat mahdollisimman suuret.

2. Rinnakkaistallentamisen helpottaminen avaimet käteen -periaatteella. Hankkeen aikana mainostimme avoimesti tutkijoille mahdollisuutta lähettää meille tiedostoja aiemmin rinnakkaistallentamattomista julkaisuistaan, jolloin rinnakkaistallentaminen hoituisi heidän puolestaan alusta loppuun. Tästä mahdollisuudesta mainitsimme (monesti ja eri tavoilla, mukaan lukien) laitosko- 
kouksissa (kohta 1), sähköpostissa kaikille tutkijoille (kohta 3), tutkimuspäivätapahtumassa (kohta 4) sekä (yleisesti) käytäväkeskusteluissa.

3. Sähköposti koko (tutkivalle) henkilökunnalle. Sähköpostissa kävimme lyhyesti läpi rinnakkaistallentamisen hyödyt ja pyysimme tutkijoita lähettämään tiedostoja aiemmin rinnakkaistallentamattomista julkaisuistaan. Näitä lupauduimme rinnakkaistallentamaan heidän puolestaan (kohta 2).

4. Läsnäolo Hankenin tutkimuspäivätapahtumassa Hankkeella oli pöytä posteriesitysten alueella, jossa meillä oli henkilökuntaa, esitteitä sekä tietokone, jonka avulla pystyimme opastamaan tutkijoita siinä, miten rinnakkaistallentamista tehdään.

5. Opetusmateriaalit Kirjaston sivulla oli jo ennestään rinnakkaistallentamisopas. Hankkeen aikana päivitimme näitä oppaita.

6. Rinnakkaistallentamiskurssit. Kirjasto järjesti koko Hankenin henkilökunnalle avoimia rinnakkaistallentamisen pikakursseja.

7. Linjausten muotoilu Tutkijoiden kanssa käydyn valistustyön lisäksi kävimme myös keskusteluja korkeakoulun päättäjien kanssa avoimen julkaisemisen merkityksestä.

\section{Tulokset}

\section{Vaihe 1 - lähtötason kartoitus}

Keräsimme Hankenin tutkimustietojärjestelmästä bibliometristä metadataa kaikista vertaisarvioiduista tiedelehtijulkaisuista (A1- \& A2-julkaisut), joita oli julkaistu vuosina 2012-2014 (yhteensä 372 kpl). Kaikki julkaisukielet huomioitiin. Seuraavaksi etsimme verkosta vapaasti löydettäviä kokoteksti -versioita näistä julkaisuista, keräten samalla tietoa jakelukanavasta ja avoimen julkaisun versiosta. Käytimme etsinnöissä Google- sekä Google Scholar -palveluita käyttäen julkaisun nimeä/otsikkoa hakukriteerinä. Mikäli yhdelle julkaisulle löytyi enemmän kuin yksi avoin kokoteksti-versio, keräsimme tietoa kolmesta ensimmäisestä, jotta kokonaiskuva saatavuudesta olisi mahdollisimman kattava. Keskimäärin $48 \%$ etsityistä julkaisuista oli vapaasti saatavilla: 50 \% vuoden 2012 julkaisuista (61 kappaletta), 47 \% vuoden 2013 julkaisuista ( 56 kappaletta), ja 48 \% vuoden 2014 julkaisuista (73 kappaletta). Kuva 1 visualisoi kaikki kerätyt havainnot Hankenin A1- ja A2-julkaisujen saatavuudesta vuosilta 2012-2014. 


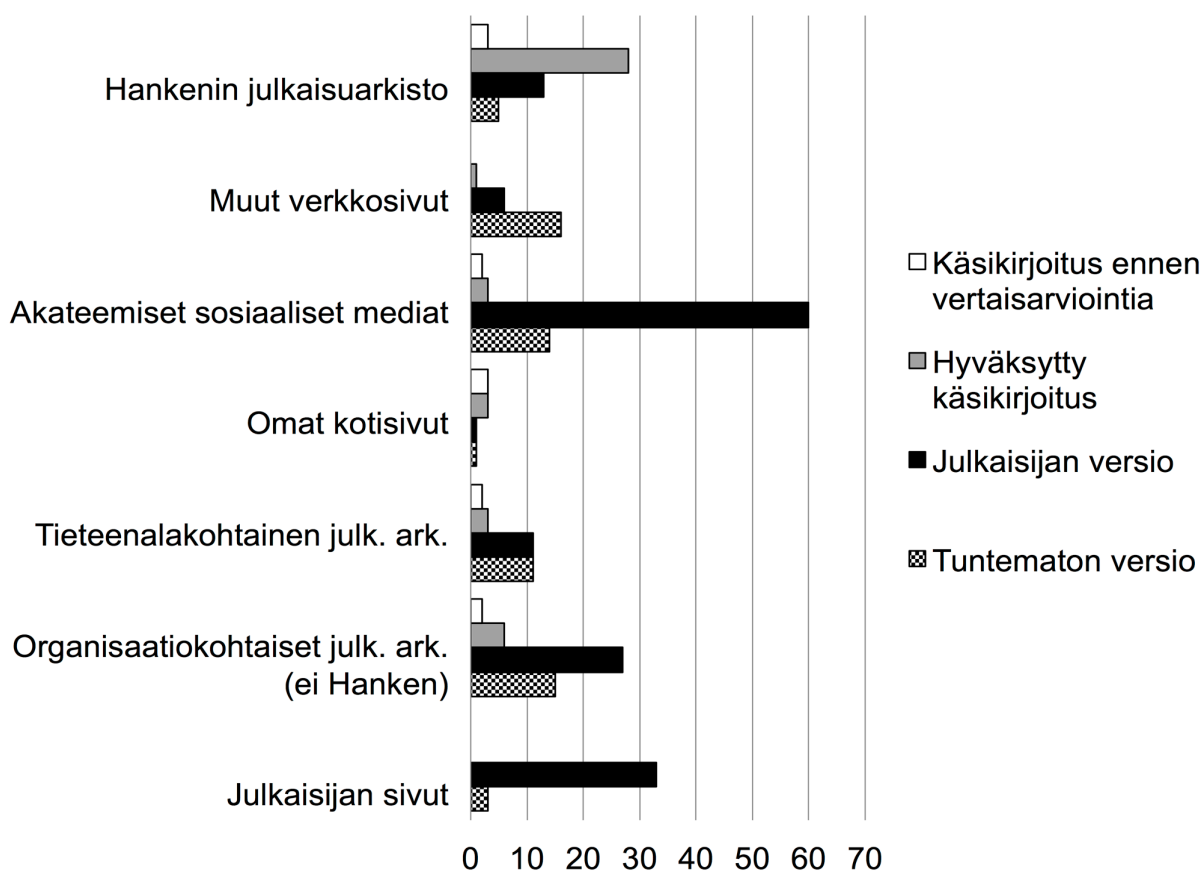

Kuva 2: Bibliometrinen lähtökartoitus - mistä tiedelehtiartikkelit löytyivät verkosta ja missä muodossa.

Yleisimmäksi julkaisujen jakelukanavaksi osoittautuivat akateemiset sosiaaliset mediat, ResearchGate ja Academia.edu: yhteensä 79 julkaisua oli ladattavissa suoraan Google Scholarin hakutuloksista näiden palveluiden mahdollistamina. Useimmat näistä olivat julkaisijan PDF-tiedostoja (6o/79, eli $76 \%$ ). Toiseksi yleisin jakelukanava oli organisaatiokohtainen julkaisuarkisto (ei sis. Hankenin oma julkaisuarkisto). Näistä löytyi yhteensä 52 julkaisua. Näin ollen Hanken-affilioituja julkaisuja löytyi enemmän muista organisaatiokohtaisista julkaisuarkistoista kuin Hankenin omasta julkaisuarkistosta, josta löytyi vain 51 julkaisua. Neljänneksi yleisin löytöpaikka oli tiedelehtien omat tai tiedelehden julkaisijan omat sivut (40 julkaisua). Viidenneksi yleisin löytöpaikka oli kategoria "muut verkkosivut", eli sivustot, jotka eivät kuuluneet mihinkään määrätyistä kategorioista (23 julkaisua), tämän jälkeen tieteenalakohtaiset arkistot ( 28 julkaisua), ja viimeisellä sijalla olivat tutkijoiden omat kotisivut (8 julkaisua).

NopSA-hankkeen tavoite oli kasvattaa Hankenin oman julkaisuarkiston kattavuutta julkaisujen rinnakkaistallentamisessa. Huomioiden ainoastaan sieltä löydetyt julkaisut, rinnakkaistallentamisen aste oli $201216 \%, 201316 \%$, ja $10 \%$ vuo- 
den 2014 julkaisujen suhteen. Rinnakkaistallentaminen julkaisuarkistoon oli alhaisin vuonna 2014, mikä on loogista ajatellen julkaisijoiden usein vaatimaa viivettä rinnakkaistallentamiseen suhteen sekä tutkijoiden taipumusta syöttää kerrallaan useamman julkaisun tiedot rinnakkaistallennusjärjestelmiin (Björk ym., 2014). Julkaisuarkiston rinnakkaistallennuksien kattavuus jakson 2012-2014 artikkeleille oli $14 \%$, luku joka toimii vertailukohtana myöhemmin, kun mahdollista muutosta tarkastellaan hankkeen loputtua.

\section{Vaihe 2 - tutkijoiden open access -näkemysten selvittäminen}

Bibliometrisen alkukartoituksen jälkeen siirryimme selvittämään Hankenin tutkijoiden näkemyksiä ja käytäntöjä avoimeen julkaisemiseen liittyen. Vaihe koostui kahdesta keskeisestä osasta: kyselystä sekä haastatteluista.

Hankenin tutkimuspäivien aikana jaetun kyselyn lisäksi suoritettiin verkkokysely. Pyyntö verkkokyselyyn osallistumisesta lähetettiin tutkivalle ja opettavalle henkilökunnalle Hankenin hallinnon toimesta. Kutsu osallistua verkkokyselyyn lähetettiin yhteensä 131 henkilölle. Käytettäviä kyselyvastauksia saimme yhteensä 43, eli 32 prosenttia kohdehenkilöistä vastasi kyselyyn. Taulukko 1 esittää kyselyvastaajien hajontaa tieteenaloittain ja Taulukko 2 vastaajien tutkimuskokemusta. Molempien tekijöiden kautta tarkasteltuna voi todeta, että vastaajat edustavat hyvin kokonaisvaltaisesti Hankenin tutkivaa henkilökuntaa.

\begin{tabular}{lc}
\hline Tieteenala & $\mathrm{n}$ \\
\hline Laskentatoimi & 7 \\
Juridiikka & 2 \\
Taloustiede & 2 \\
Yrittäjyys & 1 \\
Rahoitus & 5 \\
Tietojärjestelmätiede & 3 \\
Johtaminen & 10 \\
Markkinointi & 6 \\
Kielitiede & 2 \\
Yhteiskuntavastuu & 1 \\
Logistiikka & 4 \\
Yhteensä & 43 \\
\hline
\end{tabular}

\begin{tabular}{lc}
\hline Tutkimuskokemus & $\mathrm{n}$ \\
\hline Alle vuosi & 1 \\
1-5 vuotta & 13 \\
6-10 vuotta & 13 \\
Yli 10 vuotta & 16 \\
Yhteensä & 43 \\
\hline
\end{tabular}

Kuvat 3, 4 ja 5 esittävät keskeisimmät kyselytulokset liittyen rinnakkaistallentamiseen Hankenin julkaisuarkistoon. Tulosten perusteella voi todeta ainakin sen, 


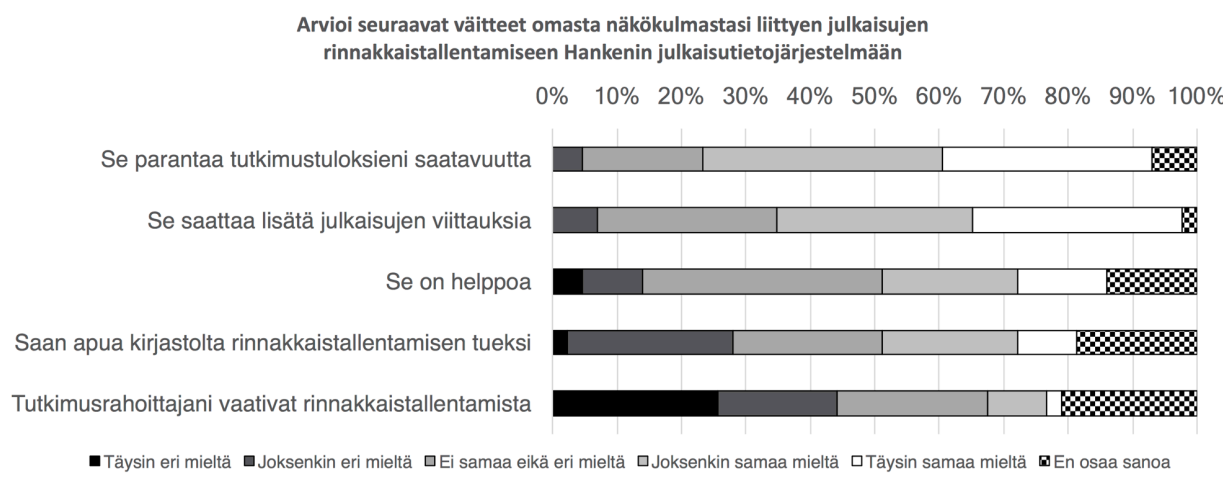

Kuva 3: Vastaajien mielipiteitä rinnakkaistallentamisesta ja Hankenin julkaisuarkistosta

että rinnakkaistallentaminen nähdään hyödyllisenä, mutta sen käytännön toteuttamiseen liittyy monenlaisia haasteita. Päällimmäisinä olivat epävarmuus julkaisijan säännöistä ja rajoituksista. Rinnakkaistallentamisen tuen kysynnän ja tarjonnan välillä näyttäisi olevan jonkinlainen jännite. Huomionarvoista on myös, että noin puolet vastaajista ei ottanut kantaa väittämään, jonka mukaan rinnakkaistallentaminen julkaisuarkistoon olisi helppoa. Mitä tulee keinoihin lisätä rinnakkaistallentamista, pelkästään tuen lisääminen ei näyttäisi yksinään riittävän, vaan lisämotivaatiota saisi mikäli samalla joko tutkimusrahoittaja tai Hanken vaatisi sitä tai/ja jos toimintaan olisi liitettävissä henkilökohtainen rahallinen kannustin.

Kuten Kuva 3 osoittaa, noin 70\% vastaajista oli sitä mieltä että rinnakkaistallentaminen edesauttaa omien tutkimustulosten saatavuutta, hieman pienempi osuus sen mahdollista positiivista vaikutusta julkaisujen viittauksiin. Tämä on kannustava luku sillä se osoittaa että rinnakkaistallentamisen mahdolliset hyödyt ovat hyvin tiedossa. Noin puolet vastaajista ei ottanut kantaa väittämään, jonka mukaan rinnakkaistallentaminen julkaisuarkistoon olisi helppoa. Tämä löydös liittyy myös seuraavaan kysymykseen jossa pyydettiin arvioimaan kirjaston tukea rinnakkaistallentamiseen liittyen. Vastaajista vain noin 30\% oli sitä mieltä että kirjasto auttaa tukemaan rinnakkaistallentamista. Nämä löydökset osoittavat että rinnakkaistallentamista on tarpeen tehdä mahdollisimman helpoksi tutkijoille sekä myös vahvistaa kirjaston resursseja jotta rinnakkaistallentamisen edellytyksiä olisi mahdollista parantaa. Kysymys joka koski tutkimusrahoittajien vaatimuksia oli odotetusti hyvin hajautettu, joskin yllättävää että noin neljäsosa vastaajista ilmoittivat, että heidän tutkimusrahoittaja ei vaadi rinnakkaistallentamista. Tässä suhteessa Suomen säätiöillä olisi varmasti avoimuuden edistämiseen parantamisen paikka.

Kuva 4 kokoaa viiden erilaisen rinnakkaistallentamisen esteen koettuja vaikutuksia. Vastaajat olivat hyvin erimielisiä rinnakkaistallentamiseen kuluvasta ajasta, 
Miten merkittävinä koet seuraavat esteet rinnakkaistallentamiselle Hankenin julkaisutietojärjestelmään

\section{$\begin{array}{llllllllllll}0 & 0 & 10 \% & 20 \% & 30 \% & 40 \% & 50 \% & 60 \% & 70 \% & 80 \% & 90 \% & 100 \%\end{array}$}

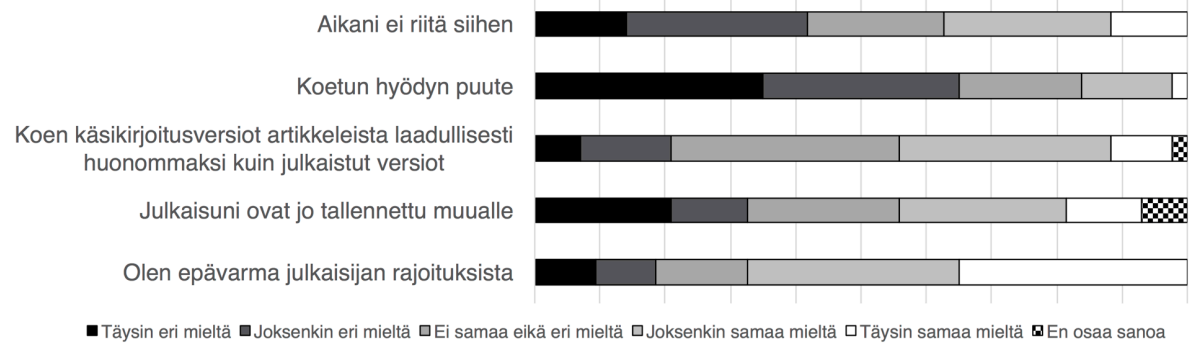

Kuva 4: Rinnakkaistallentamisen koetut esteet

Seuraavat toimenpiteet lisäisivät todennäköisesti minun rinnakkaistallentamista Hankenin julkaisutietojärjestelmään

$\begin{array}{lllllllllll}0 \% & 10 \% & 20 \% & 30 \% & 40 \% & 50 \% & 60 \% & 70 \% & 80 \% & 90 \% & 100 \%\end{array}$

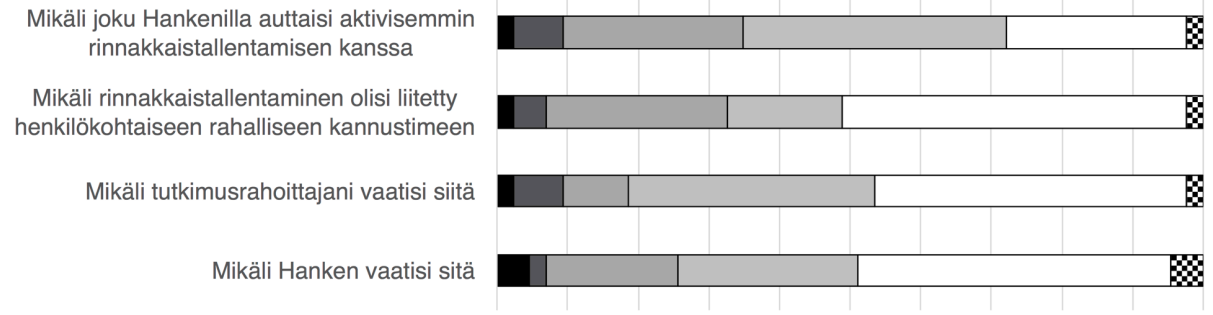

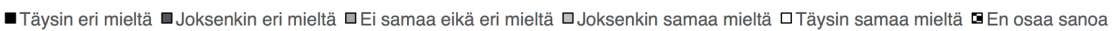

Kuva 5: Rinnakkaistallentamisen kannustimet

jossa noin kolmasosa oli sitä mieltä että aika ei riitä rinnakkaistallentamiseen. Hyödyn puute ei saanut merkittävää tukea rinnakkaistallentamisen esteenä. Noin $40 \%$ vastaajista näkivät että käsikirjoitusversio on laadullisesti huonompi kuin julkaistu versio ja näin ollen muodostaa jonkinlaisen esteen rinnakkaistallentamiselle. Vaikka bibliometrinen analyysi kertoi jo julkaisujen todellisesta saatavuudesta verkon kautta, kyselyn mukaan vain noin kolmasosa koki esteenä rinnakkaistallentamiselle sen että julkaisut ovat jo saatavilla muuta kautta. Kaksi kolmasosaa olivat epävarmoja julkaisijan säännöistä ja rajoituksista, asia johon kirjaston vahvempi tuki ja rinnakkaistallentamisen suoraviivaisemmat prosessit voisivat auttaa.

Kuva 5 tiivistää kyselytulokset jotka liittivät keinoihin lisätä rinnakkaistallentamista vastaajat arvioivat pääosin positiivisesti eri keinojen vaikutusta heidän omaan rinnakkaistallentamiseen. Kuten jo edellisistä vastauksista kävi ilmi, vahvempi tu- 
ki ja apu edistäisi monen (yli 6o\% vastaajista) heidän omaa rinnakkaistallentamista. Jos rinnakkaistallentamiseen liitettäisiin jonkinlainen henkilökohtainen rahallinen kannustin se motivoisi noin kaksi kolmasosaa vastaajista lisäämään rinnakkaistallentamista. Mikäli taas tutkimusrahoittaja tai Hanken vaatisi rinnakkaistallentamista niin yli $70 \%$ prosenttia vastaajista arvioivat sen lisäävän heidän rinnakkaistallentamista. Näiden tulosten pohjalta voisi päätellä että jonkinlainen yhdistelmä tuen lisäämisellä, vaatimuksilla, ja mahdollisella palkitsemisella voisi päästä hyviin tuloksiin rinnakkaistallentamisen edistämisessä organisaatiotasolla

Tutkijahaastattelujen kautta pyrimme ymmärtämään alkukartoituksen havaintojen taustatekijöitä. Haastatteluiden tulokset esitetään tässä neljän keskeiseen teemaan ryhmitettynä.

\section{Tietoisuus avoimesta julkaisemisesta sekä sen hyödyistä}

Yleisesti ottaen tietämys avoimen julkaisemisen mahdollisuuksista todettiin heikoksi, mutta myös avoimuuden hyödyistä oli erilaisia mielipiteitä. Jotkut tutkijat pitivät omalle uralle tärkeimpänä lähinnä viittauksia, ja että niitä tulee kuitenkin ainoastaan sellaisilta tutkijoilta, joilla on jo pääsy heidän tilauspohjaisessa lehdessä oleviin julkaisuihinsa. Kun esitimme ajatuksen, että OA todennäköisesti kasvattaisi viittauksia ja antaisi myös maallikoille, teollisuudelle sekä oman tutkimusalan ulkopuolisille mahdollisuuden päästä lukemaan julkaisut, osa tutkijoista näytti kiinnostuvan avoimesta julkaisemisesta. Useat tutkijat kertoivat tutkimusalueellaan olevan avoimia tiedelehtiä, mutta lähestulkoon poikkeuksetta tutkijat totesivat samalla, etteivät kyseiset julkaisut olleet tarpeeksi korkealaatuisia, ja ettei heitä kiinnosta julkaista artikkeleitaan niissä. Muutama tutkija luuli että "open access" viittaa ainoastaan avoimiin tiedelehtiin tai hybridi OA-julkaisumuotoon, ja tällä näkemyksellä näytti olevan suora linkki yleisesti kielteisempään OA-näkemykseen.

\section{Avoimen julkaisemisen koettu tärkeys omassa tutkimustyössä}

Selvitimme myös näkemyksiä rinnakkaistallentamisesta sekä vapaaehtoisesti toteutettuna että näkemyksiä siitä, että rinnakkaistallentamiseen olisi jonkinlaisia pakotteita. Useat totesivat, että heitä ei varsinaisesti häiritse, jos heidän artikkelinsa ovat avoimesti saatavilla, mutta harva koki asian erityisen tärkeäksi. Keskustelu pakotetusta rinnakkaistallentamisesta sai vaihtelevan vastaanoton. Useat mainitsivat tärkeänä elementtinä, ettei rinnakkaistallentaminen saisi viedä paljon aikaa, ja että siitä ei saisi koitua tutkijalle merkittävää vaivaa. Näkemykset rinnakkaistallentamiseen liittyen vaihtelivat riippuen siitä, mikä versio julkaisusta tulisi avoimeksi, koska käsikirjoitukset eivät kaikkien mielestä ole samanarvoisia julkaisijan version kanssa (tästä löydöksestä lisää kohdassa "Artikkeleiden versioiden eriarvoisuus"). 
Tutkijat totesivat myös usein, ettei “aika riitä kaivamaan tiedostoja” esiin rinnakkaistallentamista varten.

\section{Tekniset esteet}

Useampi tutkija ilmoitti, että he eivät pystyisi löytämään rinnakkaistallentamiseen tarvittavia artikkelien käsikirjoitusversioiden tiedostoja. Haastatteluissa tuli esiin se, että muun muassa Hankenin sähköpostikiintiöt olivat pitkään niin niukat, että kaikki artikkeleihin liittyvät sähköpostit liitetiedostoineen on poistettu heti, kun käsikirjoitus on hyväksytty julkaistavaksi tiedelehdessä. Silloin kun yritetään metsästää tiedostoja vuosien takaa myös tietokoneen vaihdot hankaloittavat tilannetta, tietokoneet kun eivät ole ikuisia ja koneesta toiseen siirtymisen yhteydessä tapahtuu monesti myös hakemistojen siivous.

\section{Artikkeleiden versioiden eriarvoisuus}

Useamman mielestä julkaisun ensimmäinen versio (ennen vertaisarviointia) oli usein niin kaukana lopullisesta, esimerkiksi sisällön tai kirjoitusvirheiden määrässä, että he eivät kannattaneet ajatusta sen version avoimesta levityksestä, vaikka kansisivulla olisi hyvin selkeästi esillä tieto pre-print-version statuksesta sekä viittaustiedot ja linkki julkaistuun versioon. Melkein kaikki tutkijat antoivat kuitenkin tukensa hyväksytyn käsikirjoituksen rinnakkaistallentamiselle. Suhtautuminen oli jollain myös lehtikohtaista: yksi tutkija totesi valmiutensa rinnakkaistallentamiseen ylipäätään riippuvan siitä, kuinka paljon kyseinen lehti tekee teksteihin muokkauksia vielä julkaisun viimeistelyvaiheessa. Mikäli lehti tekee paljon parannuksia, hän halusi vain julkaisijan PDF-version olevan yleisesti saatavilla.

Kukaan ei vastustanut ajatusta lopullisen version avaamisesta kirjoittajamaksua vastaan, mutta samalla kukaan ei ollut valmis maksamaan (siihen liittyviä) näitä (maksuja) omista rahoistaan. Kirjoittajamaksut sekä hybridi OA-julkaisemisessa että täysin avoimissa lehdissä, todettiin hankaliksi kahdesta syystä. Ensinnäkin, tutkimushankkeiden suunnittelu- ja hakuvaiheessa ei välttämättä ole varmuutta siitä, kuinka monelle julkaisulle on syytä budjetoida varoja, tai mitä julkaiseminen tulee maksamaan eri lehtien kautta vuosien kuluttua. Toiseksi, julkaisut syntyvät monesti projektin loputtua, mikä on ongelmallista, koska rahaa pitäisi varata julkaisukuluihin pitkälle tulevaisuuteen.

\section{Julkaisuarkisto}

Kaikki tutkijat tiesivät tutkimustietojärjestelmän ja julkaisuarkiston olemassaolosta, mutta niiden laajempi tarkoitus avoimen julkaisemisen mahdollistajana ei ollut 
hyvin tiedossa. Useat tutkijat pitivät tutkimustietojärjestelmää lähinnä raportointityökaluna, eivätkä ajatelleet organisaation julkaisuarkistoa saatavuuden mahdollistajana, esimerkiksi Google Scholar -indeksoinnin kautta. Jotkut eivät olleet tienneet, että tiedostojen lataaminen tutkimustietojärjestelmän on edes mahdollista.

\section{Vaihe 3 - pysyvän muutoksen aikaansaaminen}

Tässä kohdassa käydään läpi niitä eri lähestymistapoja, joita hankkeessa käytettiin pysyvän muutoksen tukemiseksi. Niin onnistumiset kuin myös epäonnistumisetkin on yritetty kirjata mahdollisimman totuudenmukaisesti.

\section{Esitelmiä Hankenin eri laitoksilla}

Rinnakkaistallentamiseen keskittyneet esitelmät pidettiin Hankenin laitoskokousten yhteydessä. Osallistujamäärät olivat suhteellisen alhaisia, eikä kaikkia tutkijoita tavoitettu pelkästään tämän menetelmän kautta. Yleisesti ottaen avoimen julkaisemisen tuntemus oli heikohko, ja tilaisuuksien jälkeen tutkijoilla oli monesti paljonkin kysymyksiä. Nämä käsittivät laajan skaalan julkaisemiseen liittyviä asioita, mutta yleiset aiheet olivat käytännön asioita rinnakkaistallentamisesta, tekijänoikeuskysymyksistä, sekä haasteista yleiseen julkaisuraportointiin liittyen. Kaksi ulkoista seikkaa jotka keskusteluiden kautta näyttivät vaikuttavan negatiivisesti intoon rinnakkaistallentaa, olivat akateemiset sosiaaliset mediat (ResearchGate ja Academia.edu) ja niiden tarjoama helppo julkaisujen yleinen jako sekä joillakin kauppatieteellisillä aloilla tärkeässä roolissa olevat working paper -kokoelmat. Näitä pidettiin molemmat korvaavina vaihtoehtoina Hankenin oman julkaisuarkiston käytölle. Yleisesti ottaen joka esitelmässä kuitenkin tapahtui joidenkin tutkijoiden kohdalla selvä näkemyksellinen muutos koskien rinnakkaistallentamisen tärkeyttä ja sen hyötyjen tiedostamista. Jos organisaatiossa ei ole ennen järjestetty vastaavanlaisia tapahtumia, liian suurta tietotasoa aiheesta ei kannata etukäteen olettaa. Tällaiset tilaisuudet ovat kuitenkin näiden kokemusten pohjalta hyödyllisiä ja varsin tehokkaita aktivoimaan tutkijoita.

\section{Rinnakkaistallentamisen helpottaminen avaimet käteen-periaatteella}

Lupauduimme hoitamaan kaikki rinnakkaistallentamiseen liittyvät askeleet, kunhan saisimme tutkijoilta julkaisujen käsikirjoitukset jossakin muodossa. Ainoastaan muutama tutkija tarttui tähän mahdollisuuteen. Eniten julkaisuja tuli muutamilta yksittäisiltä tutkijoilta haastatteluiden kautta. Selvästi eniten yhteydenottoja yhdellä tai useammalla artikkelilla tuli koko organisaatiolle lähetetyn sähköpostin kautta, jota käsitellään seuraavassa kohdassa. Tällaisen palvelun pitäisi olla käytössä 
pysyvästi, sillä vaikka tallentaminen Pure-järjestelmässä ei ole hankalaa, se voi silti muodostaa kynnyksen saada tutkija tekemään toimenpide täysin omatoimisesti.

\section{Sähköposti koko (tutkivalle) henkilökunnalle}

Vastauksia saimme noin 20, mutta ainoastaan muutama tiedosto oli muu kuin lopullinen tieteellisen lehden PDF-tiedosto. Ajatuksena on, että jatkossa tutkijoille lähetetään henkilökohtainen sähköposti muistutuksena, jos uuden rekisteröidyn julkaisun yhteyteen ei ole liitetty käsikirjoitusta rinnakkaistallennettavaksi. Tällainen menettely antaisi toiminnalle enemmän henkilökohtaista otetta verrattuna massasähköposteihin ja osoittaisi tutkijoille, että heidän julkaisujaan todellakin kaivataan julkaisuarkistoon.

\section{Läsnäolo Hankenin tutkimuspäivätapahtumassa}

Tämä lähestymistapa ei tuottanut juurikaan yhteydenottoja tutkijoilta. Muut vastaavat tavat odottaa tutkijoiden yhteydenottoja eivät ole suositeltavia. Rinnakkaistallentamisen kasvattaminen vaatii aktiivista markkinointia. Tutkijoihin on otettava suoraan yhteyttä, sillä harva tulee kyselemään rinnakkaistallentamisesta omaaloitteisesti.

\section{Opetusmateriaalit}

Ohjeet rinnakkaistallentamiselle uusittiin, ja ne ovat saatavilla Hankenin verkkosivuilla. Todennäköisesti harva tutkija aktivoituu rinnakkaistallentamaan pelkästään ohjeiden takia mutta ajantasaiset ja yksinkertaiset ohjeet on oltava olemassa niitä tarvitseville. Kirjasto vastaa jatkossa niiden ylläpidosta.

\section{Rinnakkaistallentamiskurssit}

Kirjasto järjesti koko Hankenin henkilökunnalle avoimia rinnakkaistallentamisen pikakursseja. Näihin ei kuitenkaan ilmestynyt juurikaan osallistujia, mikä osoitti jälleen, että markkinoinnin ja tiedottamisen pitäisi olla melko aggressiivista, jotta viesti saadaan perille. Kirjasto tarjoaa myös jatkuvasti mahdollisuuden varata aika rinnakkaistallentamisen yksityisopetukseen. Tätä mahdollisuutta mainostetaan muun muassa kirjaston nettisivuilla.

\section{Linjausten muotoilu}

Tutkijoiden kanssa käydyn valistustyön lisäksi kävimme keskusteluja korkeakoulun päättäjien kanssa avoimen julkaisemisen merkityksestä. Hanken julkaisi avoimen tieteen suuntaviivansa, jotka koskivat niin avointa julkaisemista, avointa dataa 
kuin avointa tiedettä (Hanken School of Economics, 2016). Seikka, jolla oli selkeä vaikutus avoimuuden käytäntöjen linjauksien etenemiseen, oli opetus- ja kulttuuriministeriön aloittama avoimen julkaisemisen valtakunnallinen tiedonkeruu osana julkaisutietoja.

\section{Keskustelu}

Tässä kohdassa käymme läpi tavoitteiden onnistumiset, epäonnistumiset ja haasteet, jotta vastaavat pyrkimykset hyötyisivät meidän kokemuksistamme.

Alkukartoitus oli erittäin hyödyllinen suunniteltaessa kommunikaatiostrategiaa tutkijoiden suuntaan. Tuloksista kävi hyvin ilmi, että moni tutkija oli jo tietoinen ja harjoitti rinnakkaistallentamista jollain tavalla, mutta ongelmaksi näytti muodostuvan Hankenin oman julkaisuarkiston rajallinen käyttö sekä kustantajien PDFtiedostojen rinnakkaistallentaminen viimeisimmän käsikirjoituksen sijaan.

Oli yllättävää, että moni tutkija ei ollut nähnyt rinnakkaistallentamista osana "open access" julkaisemista, vaan he mielsivät sen vain avoimena julkaisemisena suoraan tiedelehdessä. Vastaavan havainnon on tehnyt muun muassa Creaser ym. (2010). Tämä ilmiö on todennäköisesti kärjistynyt viiden vuoden sisällä, kun melkein jokainen tilauspohjainen tiedelehti markkinoi aggressiivisesti kirjoittajille maksullista open access vaihtoehtoa (hybridi OA), jolloin myös ilmiöön perehtymättömät törmäävät terminologiaan. Tämän suhteen voisi olla syytä yrittää kohentaa rinnakkaistallentamisen profilia ja arvostusta tutkijoiden keskuudessa. Useimmiten rinnakkaistallennettu versio on kuitenkin sisällöllisesti täysin samanarvoinen julkaisijan version kanssa, ja sen avoimeksi saattaminen ei maksa tuhansia euroja kuten hybridi OA tai kalliimmat täysin avoimesti julkaisevat lehdet.

\section{Rinnakkaistallennettujen julkaisujen huomattava kasvu takautuvasti}

Linjausten onnistumisista huolimatta retroaktiivisen rinnakkaistallentamisen aikaansaaminen oli huomattavasti odotettua haastavampaa. Haaste meidän osaltamme oli niinkin yksinkertainen, että monipuolisista yrityksistä huolimatta tutkijoita ei loppupeleissä voi pakottaa rinnakkaistallentamaan artikkeleitaan, eikä alkuperäistiedostoja ole aina säästetty, jotta joku muu voisi tehdä sen tutkijoiden puolesta. Voimme vain todeta, että takautuva rinnakkaistallentaminen laajalla rintamalla ei ole niin yksinkertaista kuin voisi kuvitella, vaikka kyseessä olisi pieni organisaatio. Mitä tuoreempi julkaisu sen paremmat mahdollisuudet ovat rinnakkaistallentamiselle. Tämän pohjalta ehdotimme aloitetta, jolla toivomme olevan suuria vaikutuksia. Mikäli tutkija rekisteröi uuden julkaisun julkaisuarkistoon, mutta ei samalla rinnakkaistallenna sitä, kirjasto ottaa yhteyttä tutkijaan ja pyytää kopiota tiedostosta ennen kuin on todennäköisesti liian myöhäistä ja tiedosto on kadotettu. 


\section{Hankenin avoimen julkaisemisen käytäntöjen parantaminen}

Käytäntöjen muuttaminen vaatii perusteellista suunnittelua, tiedottamista ja opetustyötä. Oli haasteellista houkutella tutkijoita erillisiin koulutustapahtumiin. Tietoiskujen järjestäminen muiden tapahtumien yhteydessä, esimerkiksi laitoskokousten yhteydessä, osoittautui huomattavasti toimivammaksi. NopSAn pohjalta voimme todeta, että yksityisopetukselle ei juuri ole kysyntää. Henkilökohtaiset tapaamiset (ryhmän koosta riippumatta) olivat mielestämme parhaita tapoja saada muutosta aikaan tutkijoiden käytännöissä. Kantamme koko hankkeen aikana on ollut se, että tutkijat saavat mielellään levittää julkaisujaan myös muiden verkkopalveluiden kautta, mutta omasta julkaisuarkistosta pitäisi kuitenkin tehdä ensisijainen paikka, johon julkaisu tallennetaan.

\section{Hankenin avoimen julkaisemisen toimintaperiaatteiden asettaminen}

Ottaen huomioon jo päätettyjä ja osittain jo toteutettuja linjauksia, jotka edistävät rinnakkaistallentamista ja avointa julkaisemista, voimme todeta NopSAn onnistuneen hyvin tältä osin. Nyt Hankenin avoimen julkaisemisen jatkuvaksi tavoitteeksi on virallisesti asetettu $80 \%$ taso kaikista vertaisarvioiduista julkaisuista. Taso on täysin realistinen, kunhan kaikki tarvittavat tiedostot säilytetään. Organisaation pieni koko ja noin 120-130 vuosittaista A1- \& A2-julkaisua merkitsevät, että jokaisella yksittäisellä rinnakkaistallennuksella on sekä henkilökohtainen että hyvin näkyvä organisaatiotasoinen vaikutus. Uskomme tämän toimivan yhdenlaisena kannustimena, sillä yksittäisten julkaisujen rinnakkaistallentamisen merkitys kasvaa.

\section{Bibliometrinen analyysi NopSAn päätyttyä}

NopSA-hankkeen keskeisiä tavoitteita oli saada lisää rinnakkaistallennettuja julkaisuja Hankenin omaan julkaisuarkistoon. NopSAn alussa toteutettu bibliometrinen analyysi näytti, että julkaisuarkiston rinnakkaistallennuksien kattavuus 2012-2014 jakson artikkeleille oli $14 \%$. NopSAn loputtua teimme toisen bibliometrisen analyysin. Silloin avoimien julkaisujen määrä Hankenin julkaisuarkistossa oli 30 \%. Näiden lisäksi löytyi suurehko määrä (noin 50) artikkelia, joihin tutkijat olivat syöttäneet linkin avoimesti julkaistuun versioon, mutta joista ei mittausvaiheessa (vielä) ollut omaa rinnakkaistallennettua versiota Hankenin omassa julkaisuarkistossa. Nämä mukaan lukien NopSAn jälkeen avointen artikkeleiden osuus nousee 44 prosenttiin. 


\section{Yhteenveto}

Hankkeen aikana kohtasimme samanlaisia haasteita, joita aikaisemman tutkimuksen kautta on tunnistettu. Kuten myös Goldman ym. (2010) sekä Creaser ym. (2010) totesivat omissa rinnakkaistallentamistutkimuksissaan, myös Hankenilla hyvin moni tutkija oli tietämätön Hankenin rinnakkaistallentamisarkiston tarkoituksesta OA:n mahdollistajana. Niistä, jotka tiesivät tästä tarkoituksesta, erittäin harvat käyttivät mahdollisuutta tarjota avointa versiota Hankenin arkiston kautta. Hankenilla, kuten myös Goldman ym. (2010) tutkimuksessa ilmeni, että vaikka tutkija toteaisi rinnakkaistallentamisarkiston arvokkaaksi tai hyödylliseksi, tämä ei johtanut konkreettisiin toimiin omien artikkeleiden rinnakkaistallentamiseksi Hankenin arkistoon. Monet tutkijat pitivät akateemisia sosiaalisia verkostoja (kuten ResearchGate) riittävinä OA-kanavina (Niyazov ym., 2016; kts. esim. Van Noorden, 2014). Näiden palveluiden epävarmuustekijät (kts. esim. Laakso \& Björk, 2016; Rousi, 2016) olivat tutkijoille pitkälti tuntemattomia.

Kuten esimerkiksi Kim (2010), pystyimme myös toteamaan, että siinäkin tapauksessa, jossa tutkija harrasti rinnakkaistallentamista, rinnakkaistallentamisen kohteeksi tutkija valitsi erittäin harvoin Hankenin arkiston. Julkaisuista raportoidaan aktiivisesti Hankenin julkaisutietojärjestelmään, mutta erittäin harvoin samalla harrastetaan raportoidun artikkelin rinnakkaistallentamista saman käyttöliittymän kautta. Muita samankaltaisia haasteita NopSAn ja Kimin (2010) tutkimuksen välillä oli tutkijoiden ajan priorisointi muihin asioihin sekä heidän epävarmuutensa tekijänoikeuskysymyksissä. Julkaisijoiden asettamat embargoajat rinnakkaistallentamiselle oli Hankenin tutkijoilla myös huonosti tunnettu aihe, mikä vastaa Creaser ym. (2010) tutkimustuloksia.

Hankenilla on tämän tutkimuksen aikana määrätty toteutettavaksi uusi OA linjaus. Aikaisemmat tutkimukset (Swan ym., 2015; Vincent-Lamarre ym., 2016) ovat todenneet tiukkojen vaatimusten edesauttavan rinnakkaistallentamisen toteutumista. Vaikka Hankenin linjaus ei pakota rinnakkaistallentamaan, se on tärkeä aloite rinnakkaistallentamisen vahvistamiseksi. Voimme toivoa nykyisen linjauksen edesauttavan rinnakkaistallentamisen toteutumista tuleville julkaisuille, mutta sen todellisen vaikutuksen kartoittaminen jää tuleville tutkimusprojekteille.

Se että akateemiset sosiaaliset verkostot olivat kaikkein yleisin sijainti Hankenin tutkijoiden julkaisuille, ei liene poikkeus, vaan mitä todennäköisemmin hyvin yleistä. Täysin vastaavaa organisaatiokohtaista bibliometristä kartoitusta ei ole muulla tehty, mutta esimerkiksi Jamali \& Nabavi (2015) totesivat, että ResearchGate on toiseksi suurin yksittäinen kokotekstitiedostojen lähde Google Scholar palvelussa heti Yhdysvaltojen National Institute of Healthin jälkeen. Kannustettaessa julkaisuarkiston käyttöön olisi hyödyllistä voida konkreettisesti osoittaa, että rinnakkaistallennetuille julkaisulle on oikeasti kysyntää, vähän vastaavasti kuin akatee- 
miset sosiaaliset verkostot tekevät monipuolisten metriikoiden kautta. Tämä voisi tapahtua Google Analyticsin tai vastaavan analyysityökalun avulla, jolloin voitaisiin säännöllisin väliajoin kommunikoida tutkijoille mitä kautta aineistoja haetaan, miten usein ja millaisilla hakusanoilla. Toinen täydentävä vaihtoehto olisi teettää verkkokysely julkaisuarkiston käyttäjille. Aikaisemmissa tutkimuksissa julkaisuarkiston käyttäjiä on jopa kutsuttu haastatteluihin kävijäprofiilien kartoittamiseksi (St. Jean, Rieh, Yakel, \& Markey, 2011), mutta webmetriikka ja verkkokysely lienevät käytännöllisemmät säännölliseen kartoittamiseen.

Rinnakkaistallentamisen edistäminen edellyttää henkilökunnalta aikaa keskittyä aiheeseen. Tutkijoita ajatellen vaaditaan sekä keppiä että porkkanaa. Tätä asiaa on syytä miettiä huolella, koska yleispäteviä ohjeita ei voida antaa. Vaaditaan tutkijoille tiedon jakamista rinnakkaistallentamisen eduista, erilaisia keinoja toteuttaa rinnakkaistallentamista, sekä rinnakkaistallentamisessa vaaditun työn ja vastuun siirtämistä mahdollisimman paljon pois tutkijoilta. Rinnakkaistallentamisen toteutettaminen heti julkaisun rekisteröinnin yhteydessä voi olla toimiva, helppo ja halpa tapa.

\section{Lähteet}

Archambault, E., Amyot, D., Deschamps, P., Nicol, A., Provencher, F., Rebout, L., \& Others. (2014). Proportion of Open Access Papers Published in Peer-Reviewed Journals at the European and World Levels: 1996-2013 (41p.). Report produced for the European Commission DG Research \& Innovation. http://science-metrix.com/en/publications/reports/proportion-of-open-accesspapers-published-in-peer-reviewed-journals-at-the

Björk, B.-C., Laakso, M., Welling, P., \& Paetau, P. (2014). Anatomy of green open access. Journal of the Association for Information Science and Technology, 65(2), 237-250. https://doi.org/10. 1002/asi. 22963

Crawford, W. (2016). Gold Open Access Journals 2011-2015. http://waltcrawford.name/goaj1115. pdf

Creaser, C., Fry, J., Greenwood, H., Oppenheim, C., Probets, S., Spezi, V., \& White, S. (2010). Authors' Awareness and Attitudes Toward Open Access Repositories. New Review of Academic Librarianship, 16(sup1), 145-161. https://doi.org/10.1080/13614533.2010.518851

Ennas, G., \& Di Guardo, M. C. (2015). Features of top-rated gold open access journals: An analysis of the scopus database. Journal of Informetrics, 9(1), 79-89. https://doi.org/10.1016/j.joi.2014. 11.007

Euroopan Komissio. (2016). H2020 Programme: Guidelines on Open Access to Scientific Publications and Research Data in Horizon 2020. Versio 3.1. https://www.openaire.eu/guidelines-onopen-access-to-scientific-publications-and-research-data-in-horizon-2020

Fortier, R., \& Laws, E. (2014). Marketing an established institutional repository: Marquette Libraries' research stewardship survey. Library Hi Tech News, 31(6), 12-15. https ://doi .org/10.1108/LHTN05-2014-0038

Goldman, R., Bhatt, J., \& Sieczkiewicz, R. (2010). Roles of engagement: Evaluating the institutional re- 
pository through scholarly communication research | iDEA: DREXEL LIBRARIES E-REPOSITORY AND ARCHIVES. https://doi.org/http://hdl.handle.net/1860/3204

Hanken School of Economics. (2016). Guidelines for open research at Hanken. https : //www. hanken. $\mathrm{fi} / \mathrm{en} / \mathrm{research} /$ open-research-and-research-ethics

Holopainen, M. (2014). OA-lehdet ja Julkaisufoorumi. Verkkari, 2014(2). http://hdl. handle. net/ $10138 / 170584$

Holopainen, M., \& Koskinen, K. (2016). Avoimen julkaisemisen hidas läpimurto. Informaatiotutkimus, 25(1-2), 16-21. http://journal.fi/inf/article/view/58979

Ilva, J., Laitinen, M., \& Saarti, J. (2016). The Costs of Open and Closed Access: Using the Finnish Research Output as an Example. LIBER Quarterly, 26(1), 13-27. https://doi.org/10.18352/lq. 10137

Jamali, H. R., \& Nabavi, M. (2015). Open access and sources of full-text articles in Google Scholar in different subject fields. Scientometrics, 105(3), 1635-1651. https://doi.org/10.1007/s11192$015-1642-2$

Johnson, R., \& Fosci, M. (2016). Putting down roots: Securing the future of open-access policies. Knowledge Exchange report of Workshop held on the 1oth of November 2015.

Kim, J. (2010). Faculty self-archiving: Motivations and barriers. Journal of the American Society for Information Science and Technology, 61(9), 1909-1922. https://doi.org/10.1002/asi.21336

Laakso, M. (2014). Green open access policies of scholarly journal publishers: a study of what, when, and where self-archiving is allowed. Scientometrics, 99(2), 475-494. https://doi.org/10.1007/ s11192-013-1205-3

Laakso, M., \& Björk, B.-C. (2016). Hybrid open access-A longitudinal study. Journal of Informetrics, 10(4), 919-932. https://doi.org/10.1016/j.joi.2016.08.002

Laakso, M., \& Lindman, J. (2016). Journal copyright restrictions and actual open access availability: a study of articles published in eight top information systems journals (2010-2014). Scientometrics, 109(2), 1167-1189. https://doi.org/10.1007/s11192-016-2078-z

Laakso, M., Lindman, J., Shen, C., Nyman, L., \& Björk, B.-C. (2017). Research output availability on academic social networks: implications for stakeholders in academic publishing. Electronic Markets, 1-9. https://doi.org/10.1007/s12525-016-0242-1

Lagzian, F., Abrizah, A., \& Wee, M. C. (2015). Critical success factors for institutional repositories implementation. The Electronic Library, 33(2), 196-209. https://doi.org/10.1108/EL-04-20130058

Mercer, H., Rosenblum, B., \& Emmett, A. (2007). A multifaceted approach to promote a university repository. OCLC Systems \& Services: International digital library perspectives, 23(2), 190-203. https://doi.org/10.1108/10650750710748496

Niyazov, Y., Vogel, C., Price, R., Lund, B., Judd, D., Akil, A., ... Shron, M. (2016). Open Access Meets Discoverability: Citations to Articles Posted to Academia.edu. PLOS ONE, 11(2). https://doi. org/10.1371/journal. pone. 0148257

Okerson, A. S., \& O’Donnell, J. J. (Toim.). (1995). Scholarly journals at the crossroads : a subversive proposal for electronic publishing (s. 242). Washington, D.C: Association of Research Libraries.

OKM. (2014). Hanke edistämään tieteen ja tutkimuksen avoimuutta. Verkkouutinen 4.3.2014. http: //minedu.fi/OPM/Verkkouutiset/2014/03/tieteen_ja_tutkimuksen_avoimuus.html

Olsbo, P. (2017). Surima-hanke ja rinnakkaistallentaminen Suomessa. Esitys Rinnakkaistallentaminen Suomessa -seminaarissa 25.1.2017. http://urn.fi/URN:NBN: fi-fe201701251319

Poltronieri, E., Bravo, E., Curti, M., Ferri, M., \& Mancini, C. (2016). Open access publishing trend analysis: statistics beyond the perception. Information research, 21(2).

Rousi, A. (2016). Essay on institutional repositories and open access. Informaatiotutkimus, 35(1-2), 22-28. http://journal.fi/inf/article/view/58980

Ruth, A.-S. (2016). DOAJ tiukensi seulaansa - miten vaikutukset näkyvät JUFOssa? http://portti. 
avointiede.fi/tutkimusjulkaisut/doaj-tiukensi-seulaansa-miten-vaikutukset-nakyvat-jufossa Salo, D. (2008). Innkeeper at the Roach Motel. Library Trends, 57(lapor), 98-123. https://doi.org/ 10.1353/lib.0.0031

St. Jean, B., Rieh, S. Y., Yakel, E., \& Markey, K. (2011). Unheard Voices: Institutional Repository EndUsers. College \& Research Libraries, 72(1), 21-42. https://doi.org/10.5860/crl-71r1

Suomen Akatemia. (2015). Avoin julkaiseminen ja tutkimusaineistojen avaaminen. http://www.aka. $\mathrm{fi} / \mathrm{fi} / \mathrm{rahoitus/nain-haet/hakuohjeet/avoin-julkaiseminen-ja-tutkimusaineistojen-avaaminen/}$

Swan, A., Gargouri, Y., Hunt, M., \& Harnad, S. (2015). Open Access Policy: Numbers, Analysis, Effectiveness. https://arxiv.org/abs/1504.02261

University of Nottingham. (2016). SHERPA/RoMEO: Publisher copyright policies and self-archiving. Van Noorden, R. (2014). Online collaboration: Scientists and the social network. Nature, 512(7513), 126-129. https://doi.org/10.1038/512126a

Vincent-Lamarre, P., Boivin, J., Gargouri, Y., Larivière, V., \& Harnad, S. (2016). Estimating open access mandate effectiveness: The MELIBEA score. Journal of the Association for Information Science and Technology, 67(11), 2815-2828. https://doi.org/10.1002/asi.23601 